\title{
PENGEMBANGAN MESIN CNC VIRTUAL SEBAGAI MEDIA INTERAKTIF DALAM PEMBELAJARAN PEMROGRAMAN CNC
}

\author{
Bambang Setyo Hari Purwoko \\ Jurusan Pendidikan Teknik Mesin FT UNY \\ bambang_shp@yahoo.co.id
}

\begin{abstract}
Abstrak
Penelitian ini bertujuan: (1) menghasilkan prototype tampilan lingkungan fisik sebuah mesin bubut CNC (Virtual Reality CNC) pada layar komputer yang dapat menerima masukan dan dioperasikan sebagaimana suatu mesin $\mathrm{CNC}$ dan (2) menguji keefektifan prototype mesin CNC Virtual tersebut sebagai media interaktif pembelajaran pemrograman CNC. Penelitian ini merupakan penelitian pengembangan. Obyek penelitian adalah rekayasa pemrograman dengan bahasa Visual Basic 6 guna menghasilkan mesin CNC Virtual. Subjek penelitian ini adalah dosen dan mahasiswa peserta kuliah CNC di FT UNY, guru dan siswa pebelajar CNC di SMK, ahli teknologi pembelajaran, dan ahli media pendidikan. Data dikumpulkan dengan observasi, kusioner, dan tes hasil belajar. Analisis data dilakukan dengan analisis deskriptif. Hasil penelitian adalah: (1) prototype media interaktif mesin CNC virtual berhasil diwujudkan sesuai perencanaan, yaitu dapat menghadirkan lingkungan fisik mesin CNC yang terdiri, kontrol panel, layar komputer, dan sistem penjepitan benda kerja, (2) prototype media dapat menyimulasikan fungsi komponen virtual seperti saklar utama, saklar pemutar spindel utama, dan tomboltombol pada mode pengoperasian $\mathrm{CNC}$ dengan baik dan mampu menampilkan simulasi gerakan pahat meskipun sebatas pada kode program tertentu, dan (3) prototype mesin $\mathrm{CNC}$ virtual efektif untuk digunakan sebagai media interaktif pembelajaran pemrograman CNC.

Kata kunci: media pembelajaran, simulasi, CNC virtual

$$
\text { Pengembangan Mesin CNC V irtual sebagai Media Interaktif - } 165
$$$$
\text { Bambang Setyo Hari Purwoko }
$$ 
THE DEVELOPMENT OF CNC VIRTUAL MACHINE AS INTERACTIVE MEDIA IN LEARNING OF CNC PROGRAMMING

\author{
Bambang Setyo Hari Purwoko \\ Jurusan Pendidikan Teknik Mesin FT UNY \\ bambang_shp@yahoo.co.id
}

\begin{abstract}
This research aims are: (1) produce a prototype of Virtual Reality $\mathrm{CNC}$ that present the physical appearance of $\mathrm{CNC}$ lathe in the computer screen which can be inputing data and operates as a real $\mathrm{CNC}$ machine, (2) evaluate the effectiveness of prototype as instructional media of $\mathrm{CNC}$ programming. Methode of this research is a Research and Development (R\&D). The object is software engineering. The based of engineering is Visual Basic 6. The subject were lecturers and students of CNC class in FT UNY, teachers and students of $\mathrm{CNC}$ class in vocational school (SMK), the expert of learning technology, and the expert of learning media. The data were collected by observation, questioner, and evaluation test. The data is analized by descriptive analysis. The results of this research were: (1) prototype of Virtual Reality $\mathrm{CNC}$ has been realized appropriated with the plan, which is could present the physical appearances of CNC machine which consist of control panel, computer screen, and clamped system, (2) prototype could simulates the use of virtual components such as main switch, main spindle switch, and buttons in operational mode on CNC machine well and could present the simulation of tool path motion although just in the certain code programmed, and (3) the prototype was effective as instructional media of $\mathrm{CNC}$ programming.
\end{abstract}

Keywords: instructional media, simulation, Virtual CNC 


\section{Pendahuluan}

Bertepatan hari Pendidikan Nasional tanggal 2 Mei 2006 Departemen Pendidikan Nasional (Depdiknas) menetapkan Rencana Strategis Pembangunan Pendidikan. Restra tersebut memuat peningkatan relevansi dan daya saing mutu pendidikan yang harus secara nyata diwujudkan dalam pengajaran (teaching), pembimbingan (guiding), dan pelatihan (training). Pengajaran untuk memberikan pengetahuan, pembimbingan untuk menanamkan sikap konstruktif, sedangkan pelatihan untuk meningkatkan keterampilan.

Sidi (2001: 37) menyatakan, guru merupakan salah satu faktor dominan yang sangat menentukan tingkat keberhasilan anak didik melakukan transformasi ilmu pengetahuan dan teknologi, serta internalisasi etika dan moral, namun bukan satu-satunya sumber belajar. Menurut Winarno Surakhmad (Pannen, dkk, 1999: 6), penyelenggaraan pendidikan memerlukan terpenuhinya persyaratan tertentu, termasuk infrastruktur pendidikan yang memadai. Tidak terpenuhinya persyaratan yang ditetapkan akan mengakibatkan proses pembelajaran menjadi tidak berkualitas dan sasaran pembelajaran tidak dapat dicapai.

Salah satu kekurangan infrastruktur pendidikan di Jurusan Teknik Mesin, baik di perguruan tinggi maupun di SMK adalah terbatasnya jumlah mesin CNC untuk proses pembelajaran pemrograman CNC. Bahkan banyak perguruan tinggi dan SMK penyelenggara program studi teknik mesin tidak memiliki mesin $\mathrm{CNC}$, dikarenakan kondisi lembaga yang tidak memungkinkan untuk membeli mesin $\mathrm{CNC}$ yang harganya masih relatif mahal.

Di lembaga dengan jumlah mesin CNC terbatas, proses pembelajaran CNC dilakukan secara berkelompok dan bergiliran dalam mengoperasikan mesin. Satu kelompok terdiri dari 4 sampai 5 orang mahasiswa. Sedangkan di lembaga yang sama sekali tidak/belum memiliki mesin $\mathrm{CNC}$, maka proses pembelajaran $\mathrm{CNC}$ dilakukan tanpa kegiatan praktik menggunakan mesin CNC.

Kesempatan berinteraksi dengan mesin CNC yang berbeda-beda antarmahasiswa/siswa, saat praktik membuat program $\mathrm{CNC}$ maupun

$$
\begin{gathered}
\text { Pengembangan Mesin CNC Virtual sebagai Media Interaktif - } 167 \\
\text { Bambang Setyo Hari Purwoko }
\end{gathered}
$$


pengoperasian mesin $\mathrm{CNC}$ ini menyebabkan kesenjangan perolehan hasil belajar. Mahasiswa/siswa yang memperoleh kesempatan berinteraksi dengan mesin CNC memiliki pengalaman lebih banyak dan kemampuan lebih baik, sedangkan yang kurang aktif/tidak berkesempatan berinteraksi dengan mesin $\mathrm{CNC}$, tidak memiliki pengalaman dan cenderung tidak dapat mencapai standar kompetensi yang ditetapkan.

Permasalahan pembelajaran CNC demikian, perlu segera diatasi. Salah satu alternatifnya adalah dengan mengembangkan media simulasi visual graphic mesin CNC (mesin CNC Virtual), yaitu program komputer yang apabila dijalankan akan menampilkan gambar dua dimensi mesin CNC lengkap dengan tombol-tombol pengoperasiannya pada layar komputer (monitor). Tombol-tombol pengoperasian virtual pada layar dapat berfungsi sebagaimana fungsi tombol pada mesin $\mathrm{CNC}$ sesungguhnya. Media simulasi visual graphic ini representasi dari mesin CNC, dapat berfungsi (1) mensimulasikan fungsi-fungsi tombol pada panel kontrol, (2) mensimulasikan pemasukan program CNC (data input) ke dalam sistem kontrol mesin $\mathrm{CNC}$, dan (3) mensimulasikan jalannya pembacaan (eksekusi) program CNC berupa animasi jalannya proses pemesinan pada mesin CNC.

Permasalahan pengembangan Mesin CNC Virtual (Virtual Reality $\mathrm{CNC}$ ) sebagai media pembelajaran pemrograman $\mathrm{CNC}$ adalah:

1. Apakah prototype media simulasi visual graphic mesin $\mathrm{CNC}$ yang dapat menampilkan secara layak visualisasi lingkungan nyata suatu mesin $\mathrm{CNC}$ pada layar komputer?

2. Apakah prototype mesin CNC virtual tersebut efektif sebagai media pembelajaran pemrograman $\mathrm{CNC}$ ?

Bentuk pemanfaatan komputer dalam pembelajaran adalah sebagai media interaksi dan aplikasi pembelajaran yang bersifat praktik dan latihan (drill \& practice), simulasi (simulation), penemuan (discovery), tutorial, pemecahan masalah (problem solving), dan permainan (games). Pemakaian komputer dalam pembelajaran mempunyai tiga tujuan, yaitu penguasaan kognitif, psikomotor, dan afektif. Untuk tujuan kognitif, komputer dapat mengajarkan konsep-konsep aturan, prinsip, langkah-langkah, proses, dan kalkulasi yang kompleks. Komputer juga dapat menjelaskan konsep 
tersebut secara sederhana dengan penggabungan visual dan audio yang dianimasikan, sehingga cocok untuk kegiatan pembelajaran mandiri.

Pada penguasaan psikomotor, komputer dapat menyajikan pembelajaran yang dikemas dalam bentuk game \& simulasi yang sangat bagus digunakan untuk menciptakan kondisi dunia kerja. Beberapa contoh program antara lain; simulasi pendaratan pesawat, simulasi perang dalam medan yang paling berat, dan sebagainya. Penguasaan afektif dapat dilakukan bila program didesain secara tepat dengan memberikan potongan klip suara atau video yang isinya menggugah perasaan. Dengan demikian, pembelajaran sikap/afektif pun dapat dilakukan mengunakan media komputer.

Simulasi secara umum dapat digolongkan menjadi tiga macam. Pertama, simulasi interaktif dan fisikal. Simulasi fisik lebih mengacu pada simulasi objek fisik untuk menggantikan sistem nyata. Objek fisik ini sering dipilih sebab mereka lebih kecil atau lebih murah dibanding sistem atau objek yang nyata, seperti pada simulator penerbangan.

Kedua, simulasi komputer, yaitu suatu usaha untuk meniru situasi nyata dalam suatu komputer, sehingga situasi dapat dipelajari untuk dilihat bagaimana sistem itu bekerja. Dengan mengubah variabel, kemungkinan peramalan dapat dibuat tentang perilaku sistem itu.

Ketiga, simulasi dalam pelatihan tanpa harus mengeluarkan biaya yang mahal dan atau situasi berbahaya. Simulasi tentang lingkungan nyata yang dibuat oleh komputer dan pengguna dapat berinteraksi dengan hasil yang menampakkan isi dari kenyataan lingkungan disebut kenyataan virtual (Virtual Reality). VR (Wen \& Shih, 2003) merupakan suatu format interaksi manusia-komputer di mana suatu lingkungan nyata atau khayal disimulasikan dan para pemakai dapat berhubungan dan menggerakkan dunia itu. Dalam lingkungan virtual yang paling berhasil, para pemakai merasakan bahwa mereka sungguh-sungguh hadir di dunia yang disimulasikan dan bahwa pengalaman mereka di dalam dunia virtual sebanding dengan apa yang akan mereka alami pada lingkungan sebenarnya.

Virtual Reality dapat diterapkan pada berbagai bidang. Di dalam riset teknik dan ilmiah, lingkungan virtual digunakan secara visual untuk

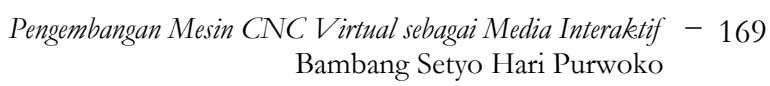


menyelidiki apapun yang terjadi pada peristiwa dunia fisik yang sedang dalam pengamatan. Pelatihan untuk pekerjaan pada lingkungan berbahaya atau dengan peralatan mahal lebih baik dilaksanakan melalui simulasi. Misalnya, pilot pesawat udara berlatih dengan simulator penerbangan. Kenyataan virtual memungkinkan personil medis untuk praktik prosedur pembedahan baru pada individu yang ditirukan (manusia tiruan).

Salah satu indera yang banyak digunakan untuk mendapatkan informasi dari lingkungannya adalah penglihatan. Indera penglihatan digunakan lebih dari indera yang lain dalam memproses informasi. Banyak penelitian psikologi menunjukkan bahwa lebih banyak informasi dapat dimengerti ketika disajikan dalam bentuk visual, dibandingkan penyajian dalam bentuk nonvisual.

Pelatihan dengan VR bisa sangat mengurangi biaya dibandingkan dengan pelatihan secara biasa. Kebutuhan akan peralatan pelatihan yang mahal dalam laboratorium nyata, atau peralatan tambahan untuk pelatihan dapat dikurangi. Keuntungan menggunakan VR sebagai alat pelatihan adalah: (1) mengurangi waktu pelatihan dalam lingkungan nyata, (2) dapat mengadakan pelatihan dalam kondisi yang sangat berbahaya, (3) lebih menghemat biaya pada pelatihan yang sama, (4) menyediakan akses tak terbatas kepada peralatan yang mahal, (5) menghapuskan biaya bepergian ke pusat pelatihan, (6) biaya perbaikan/penggantian mesin-mesin mahal dikurangi, dan (7) memungkinkan pelajar bisa berada di suatu area geografis yang luas.

Mesin CNC (Computer Numerical Control) (Groover, dkk., 1984: 5) adalah mesin yang proses pengoperasiannya dikendalikan oleh sistem $\mathrm{CNC}$, yaitu suatu sistem kontrol yang proses pengontrolannya dilakukan menggunakan perintah berupa kode-kode huruf dan angka (alpha-numericcode). Susunan perintah dalam kode huruf dan angka yang tersusun sedemikian rupa dan digunakan untuk mengatur operasi mesin dalam rangka pembuatan suatu produk disebut program $\mathrm{CNC}$.

Mesin CNC dapat dioperasikan dengan dua pilihan, yaitu secara manual dan otomatis menggunakan program CNC. Mesin CNC untuk dapat beroperasi sedikitnya memiliki tiga komponen utama, yaitu program CNC (NC part Program), Machine Control Unit (MCU) yang berfungsi untuk 
memproses data masukan, dan mesinnya sendiri yang biasanya mesin perkakas (machine tools).

\section{Metode Penelitian}

Penelitian ini merupakan penelitian pengembangan. Pelaksanaan penelitian dirancang dengan tahapan tersaji pada Gambar 1.

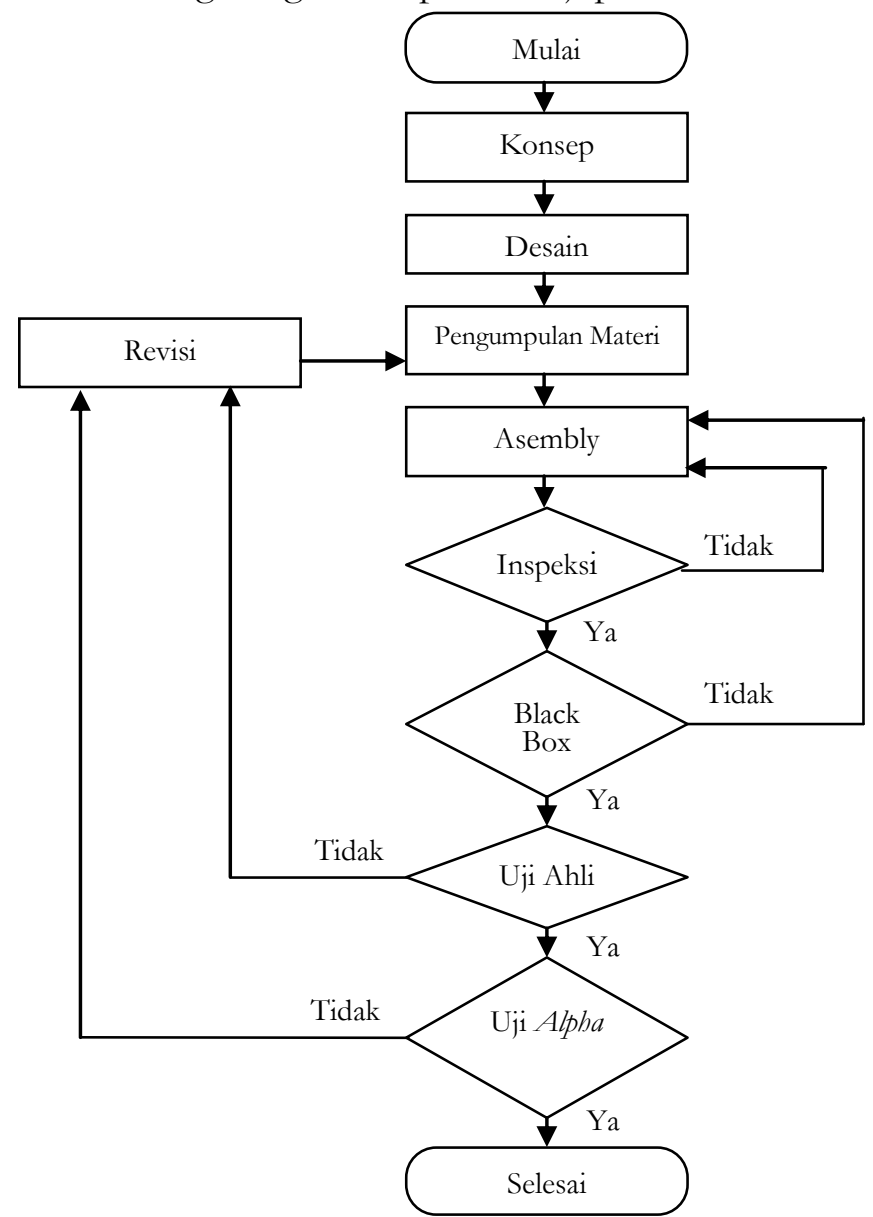

Gambar 1. Diagram Alir Proses Penelitian Pengembangan

Pengembangan Mesin CNC Virtual sebagai Media Interaktif - 171 Bambang Setyo Hari Purwoko 
Target penelitian adalah menghasilkan Media CD Simulasi Visual Graphic Pemesinan NC, untuk digunakan sebagai media pembelajaran Pemesinan NC di kelas dan media belajar mandiri. Tahapan penelitian Soenarto (2005), pertama, pendefinisian konsep produk. Produk berupa program komputer yang menghadirkan visualisasi lingkungan fisik mesin CNC di layar komputer. Program komputer dikembangkan berbasis bahasa pemrograman Visual Basic 6 Agung (2004) dengan Sistem Operasi Windows. Acuan untuk pengembangan visual adalah mesin bubut $\mathrm{CNC}$ tipe training merk EMCO dan fungsi-fungsinya.

Tahap kedua, pengembangan desain, meliputi desain fisik software, fungsi, logika, serta flowchart yang menggambarkan alur kerja produk. Ketiga, penentuan bahan/materi, dilakukan dengan meminta pendapat ahli $\mathrm{CNC}$, terdiri dari 2 orang dosen pengajar $\mathrm{CNC}, 2$ orang guru CNC SMK, 1 orang praktisi CNC di industri, 2 orang instruktur CNC. Pengumpulan pendapat menggunakan Teknik Delphi, dilakukan dalam dua putaran. Putaran pertama menjaring pendapat ahli mengenai materi, dan klasifikasi materi. Putaran kedua meminta persetujuan akhir dari ahli mengenai hasil klasifikasi dan jenis-jenis materi/bahan visualisasi.

Keempat, pengujian produk, dilakukan mengikuti teknik pengujian rekayasa perangkat lunak (Sommerville, 2003: 18), yaitu verifikasi dan validasi. Verifikasi Williams (2004) dilakukan oleh peneliti sendiri, meliputi pemeriksaan sistem perangkat lunak, dan pengujian Kotak Hitam (black-box testing), yaitu pengujian sistem dengan cara memberi input dan menganalisis output yang dihasilkan. Validasi adalah pengujian para ahli terhadap produk, dilakukan oleh 7 orang ahli CNC, 2 orang ahli Media Pembelajaran, dan 1 orang ahli dalam Teknologi Pembelajaran. Pengujian dilakukan di Laboratorium CNC Jurusan Pendidikan Teknik Mesin FT UNY, bertujuan menguji produk, memberi masukan untuk perbaikan sehingga produk memenuhi spesifikasi yang diinginkan. Pengujian $A \not p h a$, adalah pengujian awal produk oleh pengguna (16 mahasiswa), untuk melihat sejauh mana produk dapat berhasil pada penggunaan pembelajaran. 


\section{Hasil Penelitian dan Pembahasan}

Produk yang dikembangkan adalah media simulasi visual graphic mesin CNC. Sebagai referensi atau rujukan pengembangan adalah mesin CNC TU-2A, yaitu mesin bubut CNC tipe training merk EMCO buatan pabrik EMCO Maier Austria. Mesin CNC jenis ini dipilih karena digunakan secara luas di perguruan tinggi, dan SMK. Produk dikembangkan menggunakan pemrograman Visual Basic 6, dioperasikan dengan Sistem Operasi Windows XP. Hasil pengembangan berupa program komputer, yang dapat menghadirkan efek visual lingkungan fisik mesin CNC pada layar komputer. Lingkungan fisik mesin $\mathrm{CNC}$ yang ditampilkan meliputi panel kontrol, monitor, dan penjepitan benda kerja pada mesin.

Desain tampilan panel kontrol dibuat mirip dengan panel kontrol mesin CNC TU-2A periksa Gambar 2. Hal ini dimaksudkan agar situasi dan perasaan pengguna seolah-olah sedang berada atau menghadapi sebuah papan kontrol mesin CNC TU-2A yang sesunguhnya. Di samping merasa nyaman dalam menggunakannya juga akan merasakan sensasi tantangan yang mirip dengan tantangan ketika menangani mesin yang nyata. Tampilan panel kontrol diperlihatkan dalam Gambar 2.

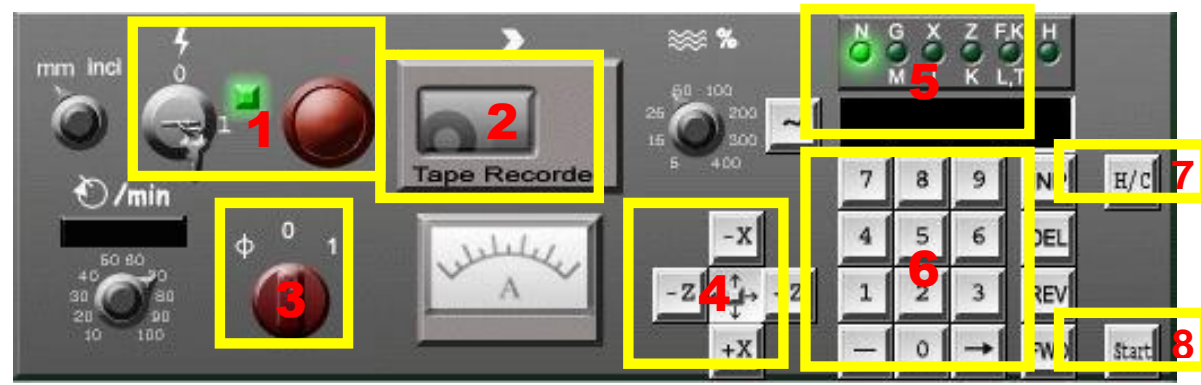

Gambar 2. Papan Kontrol

Tidak semua panel dan tombol yang divisualkan pada panel kontrol fungsinya dapat disimulasikan, beberapa hanya merupakan gambar atau sebagai hiasan agar terkesan papan kontrol lebih interaktif dan nyata. Hanya saklar dan tombol yang sering digunakan fungsinya dapat 
dioperasikan atau disimulasikan. Saklar dan tombol tersebut sebagai berikut.

1. Saklar utama (main switch). Saklar ini dapat disimulasikan dalam dua posisi, yaitu posisi "0" dan "1" (ON/OFF). Fungsi saklar utama untuk menyalakan dan mematikan Mesin CNC. Tombol emergency stop. Tombol berwarna merah, di sebelah kanan Saklar Utama ini tidak disimulasikan sehingga fungsinya hanya sebagai pelengkap tampilan.

2. Pelayanan kaset, pada media ini program yang telah dibuat dapat disimpan ke dalam bentuk file text (dengan format "*.vnc" atau "*.txt"), dan program tersebut dapat dipanggil kembali untuk dijalankan atau diedit.

3. Saklar spindel utama. Saklar ini dapat disimulasikan dalam tiga posisi, yaitu posisi "0", "1", dan "CNC". Fungsi saklar untuk menyalakan spindel utama baik pada fungsi pengoperasian $\mathrm{CNC}$ maupun fungsi pengoperasian manual.

4. Tombol pengoperasian secara manual, yaitu tombol penggerak pahat pada arah sumbu X dan Z secara manual.

5. Display Address. Bentuknya adalah lampu indikator dan LCD display untuk memunculkan kode dan data (program NC) yang akan dimasukkan ke dalam komputer Unit Kontrol Mesin.

6. Tombol Pengoperasian CNC, yaitu Numpad untuk menuliskan kode dan angka (program NC) yang dibuat pada layar komputer dan memasukkannya ke dalam memori, dan tombol-tombol yang berfungsi dalam pengeditan program, yaitu DEL untuk menghapus karakter yang tertulis, REV untuk menggerakkan kursor ke baris sebelumnya, dan FWD untuk menggerakkan kursor ke baris berikutnya.

7. Tombol H/C untuk merubah program dari layanan $\mathrm{CNC}$ ke layanan manual dan sebaliknya.

8. Terakhir adalah tombol start untuk memulai menjalankan program yang telah ditulis.

Layar komputer adalah layar tempat penulisan program, yaitu bagian yang menampilkan program CNC yang ditulis, fungsinya sama seperti monitor pada mesin CNC. Bagian ini menampilkan daftar perintah sesuai 
urutan yang akan dieksekusi jika program dijalankan. Tampilan layar penulisan program disajikan pada Gambar 3

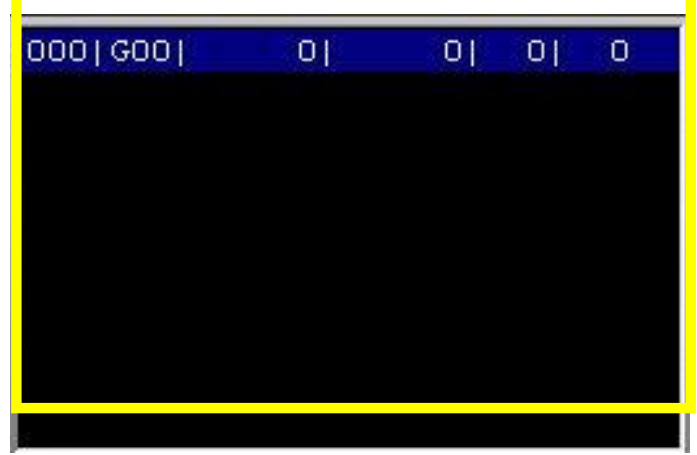

Gambar 3. Layar Penulisan Program

Jendela Animasi. Pada bagian ini animasi pembubutan ditampilkan. Jendela animasi terdiri dari beberapa komponen utama dan komponen pendukung. Komponen utamanya adalah; (1) pencekam, (2) benda kerja, (3) senter kepala lepas, (4) pahat bubut, (5) penggaris, (6) blok-milimeter (grid), (7) posisi koordinat, (8) titik pusat koordinat dan (9) tombol untuk mengubah tampilan dari jendela animasi ke jendela ploter. Tampilan Jendela animasi diperlihatkan dalam Gambar 4.

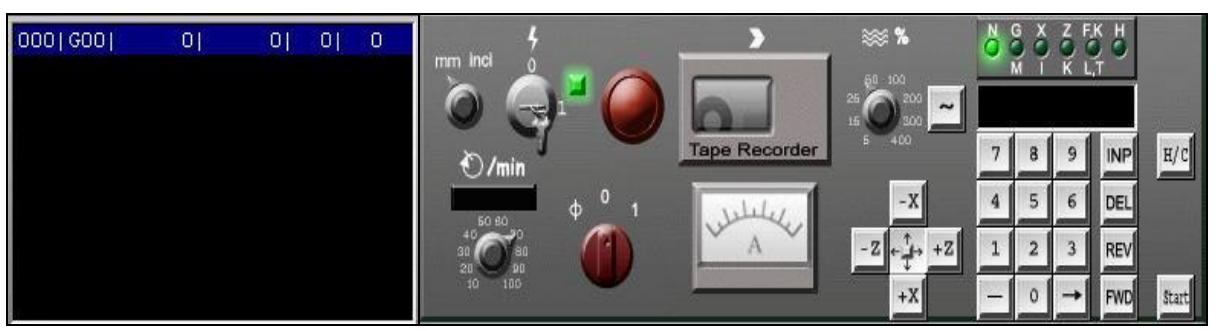




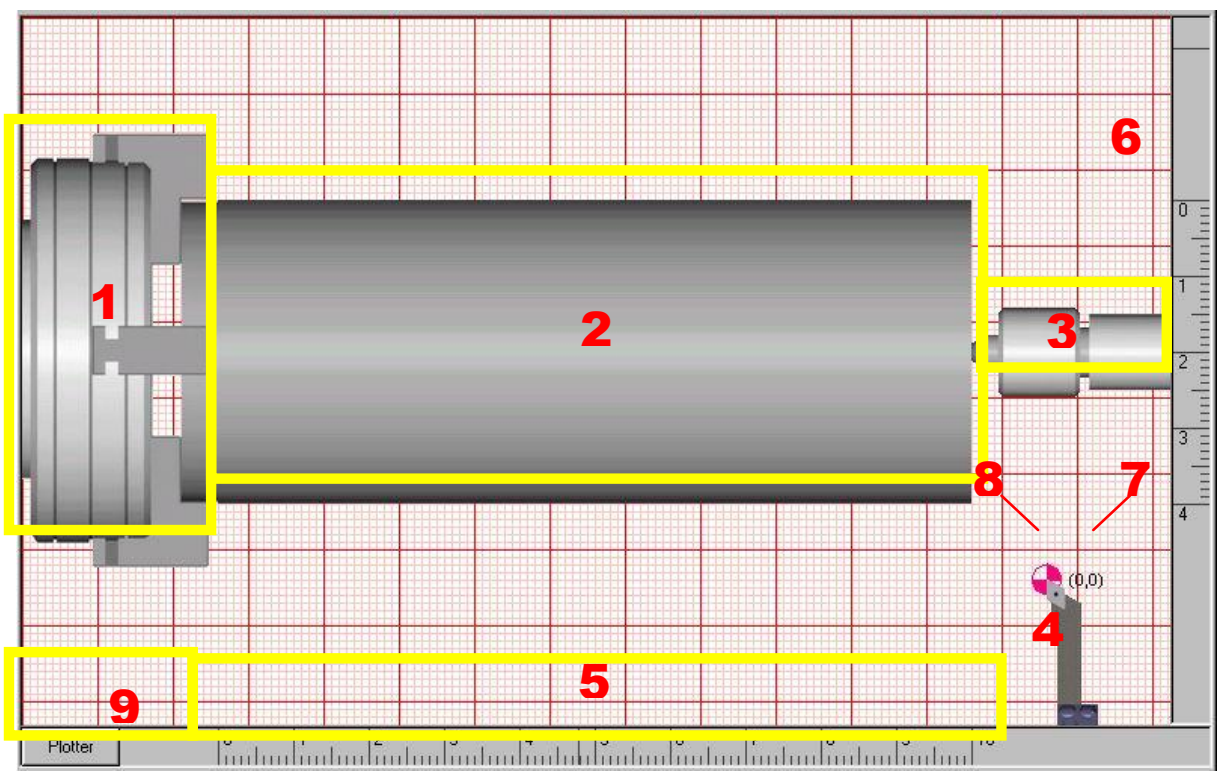

Gambar 4. Jendela Animasi

Berdasarkan rancangan tampilan, produk dapat dibuat sesuai rancangan dan mampu menampilkan sosok mesin CNC khususnya bagianbagian utama yang visualisasinya memberi efek kehadiran mesin yang sebenarnya (menampilkan papan kontrol, pencekaman benda kerja, dan pisau dengan komposisi dan proporsi yang seimbang).

Fungsi program dibuat dalam dua model layanan yaitu layanan manual dan layanan CNC. Layanan manual mempunyai tiga fungsi utama yaitu: (1) fungsi untuk menggerakkan pahat maju dan mundur sesuai dengan arah sumbu $\mathrm{X}$ dan $\mathrm{Z}$ dengan menggunakan tombol "X+", "X-", "Z+", dan "Z-"; (2) menentukan letak pahat pada posisi 0 pada sumbu X dan Z dengan menekan tombol "DEL"; dan (3) fungsi memutarkan spindel utama mesin, dengan menempatkan posisi saklar spindel utama pada angka "1".

Pada fungsi CNC, tombol ketik virtual dapat berfungsi untuk menuliskan, mengubah, dan memperbaiki program CNC pada layar 
monitor dengan baik. Fungsi tombol angka "0" sampai dengan "9", tombol "INP", "DEL", "REV", dan "FWD" virtual dapat berfungsi untuk menulis dan mengedit data masukan dengan baik. Demikian pula tombol "START", dan saklar utama ON/OFF dapat dioperasikan fungsinya identik dengan fungsi tombol tersebut pada mesin CNC. Salah satu kelebihan produk yang dikembangkan adalah dapat menyimpan program CNC yang telah ditulis, memanggil program yang tersimpan untuk diaktifkan dan ditampilkan pada layar.

Di samping itu, program $\mathrm{CNC}$ yang tertulis pada jendela penulisan program CNC juga dapat dijalankan. Program yang tertulis merupakan masukan (input) yang dapat diproses menjadi keluaran (output). Respon atau keluaran atas masukan yang diberikan, divisualkan sebagai jalannya pembacaan (ekskusi) program $\mathrm{CNC}$ oleh unit kontrol mesin. Jalannya program CNC dapat diamati melalui simulasi gerakan perkakas sayat pada jendela animasi di layar komputer.

Respon dari masukan yang berupa perintah (kode) pemrograman CNC dapat disimulasikan dengan animasi gerakan pahat bubut relatif terhadap benda kerja. Kode pemrograman CNC yang dapat diproses dan dianimasikan masih terbatas, yaitu hanya terbatas pada kode perintah yang sering digunakan pada awal latihan pembuatan program $\mathrm{CNC}$ untuk mesin CNC TU-2A. Kode-kode perintah tersebut di antaranya: kode "G00", "G01", "G02", "G03", "G90", "G91", "G92" "M03", "M05" dan "M30". Hasil Animasi jalannya program dapat dilihat pada Gambar 5. 


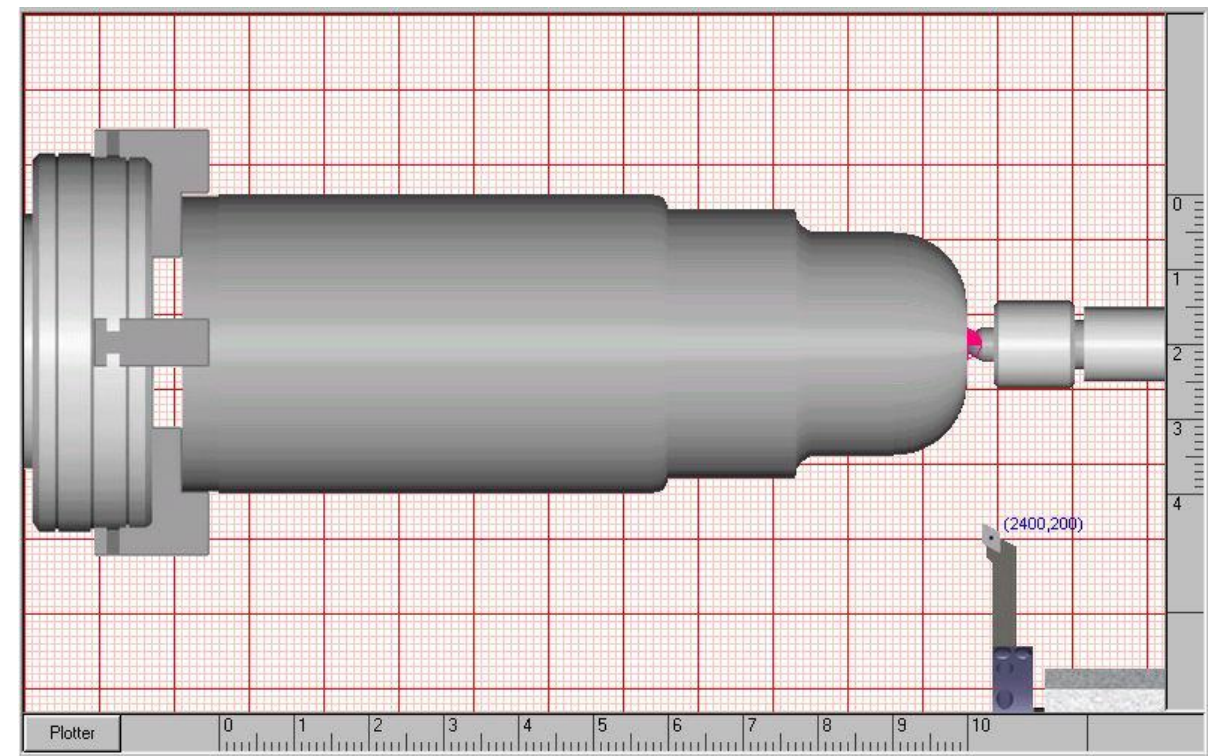

Gambar 5. Hasil Animasi Ekskusi Program CNC

Dapat disimpulkan bahwa penelitian ini berhasil mengembangkan software program CNC Virtual, yaitu suatu program berbasis komputer yang menghadirkan efek visual prinsip pengoperasian Mesin CNC, dalam hal ini CNC TU-2A pada layar komputer. Software program dapat menginisiasi, melakukan translasi (penerjemahan), dan memberi respon setiap masukan (input) dengan baik. Respon (output) hasil inisiasi dan penerjemahan dari masukan berupa kode-kode perintah dalam program NC, secara visual tidak berbeda dengan respon yang dilakukan oleh mesin $\mathrm{CNC}$ yang sebenarnya apabila sistem kontrol mesin diberi masukan yang sama.

Meskipun dalam pengembangan produk, khususnya tampilan telah berhasil dengan segala kekurangan dan kelebihannya, akan tetapi produk pengembangan belum mampu menampilkan animasi jalannya program untuk semua jenis kode perintah. Usaha pengembangan penerjemahan program CNC ke animasi sudah dapat dibuat meskipun masih terbatas untuk beberapa kode-kode dasar dan sederhana, sehingga produk sudah dapat untuk digunakan melatih pemrograman mesin CNC tingkat dasar 
secara memadai.

Hasil pengembangan produk dilihat dari kriteria produk sebagai suatu media pembelajaran menyangkut dua hal; (1) produk mampu memberikan gambaran dan efek visual fungsi operasional mesin $\mathrm{CNC}$ sehingga dapat menjadi media yang dapat memberi pengalaman visual kepada pengguna, dan (2) produk mampu memperjelas konsep bahan/materi pembelajaran sehingga dapat membantu pengguna dalam memahami materi pembelajaran dengan baik.

Berdasarkan kriteria produk sebagai media yang memvisualkan mesin $\mathrm{CNC}$, dapat dijelaskan bahwa produk memiliki tampilan baik, terutama dilihat dari segi format tampilan, keserasian bentuk dan warna, dan kesesuaiannya dengan papan kontrol mesin yang sesungguhnya. Di samping itu produk yang dikembangkan juga mudah digunakan/dioperasikan, dan mampu membangun interaksi dengan baik antara pengguna dan media yang sedang digunakan. Oleh karena itu, produk dapat menjadi sarana latihan pembuatan program $\mathrm{CNC}$, sarana berinteraksi langsung, dan sarana yang memungkinkan pengguna belajar mandiri secara baik.

Berdasarkan kriteria sebagai media yang mampu membantu memperjelas konsep bahan ajar, dapat diketahui bahwa produk yang dikembangkan materinya mampu memperjelas konsep bahan ajar dengan baik, karena materi-materi yang divisualkan produk memiliki kesesuaian dengan materi pembelajaran Pemesinan NC, misalnya materi tentang kodekode pemrograman, dan pembuatan program NCnya. Di samping kesesuaian materi yang diajarkan juga terdapat kesesuaian antara animasi gerakan pahat yang dilakukan produk dengan gerakan pahat yang sesungguhnya dalam mesin CNC. Hal ini menyebabkan pengguna menjadi lebih dapat memahami materi konsep pemrograman, karena konsep tersebut dapat secara langsung divisualkan melalui animasi pada produk yang dikembangkan. Hasil animasi dari jalannya ekskusi program NC diperlihatkan pada Gambar 6. 


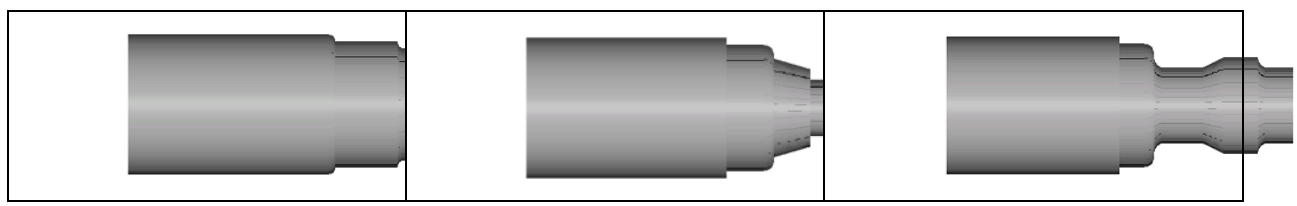

Gambar 6. Hasil Simulasi Ekskusi Program CNC

\section{Simpulan}

1. Prototype produk Simulasi Visual Graphic yang dikembangkan telah berhasil diwujudkan sesuai perencanaan menggunakan software Visual Basic 6 sebagai basis rekayasa. Produk menampilkan visualisasi lingkungan fisik mesin bubut CNC yang meliputi kontrol panel lengkap dengan asesoris dan tombol pengoperasiannya, sistem pencekaman (clamping) benda kerja, pahat bubut, simulasi fungsi operasi, dan animasi jalannya proses pemesinan dari program NC yang dijalankan. Beberapa perintah pemrograman $\mathrm{CNC}$ yang dibuat dapat digunakan dengan baik, walaupun masih terdapat bug pada kode-kode tertentu, sehingga masih memerlukan revisi dan pengembangan lebih lanjut.

2. Prototype layak dan memenuhi persyaratan sebagai media pembelajaran CNC, dengan kriteria sebagai berikut:

a. Kualitas baik dari segi tampilan, navigasi dan pengoperasian, maupun pada interaksinya terhadap pengguna, namun perlu peningkatan dari segi, komposisi warna, dan kemampuan melakukan simulasi dan animasi kode program-program $\mathrm{CNC}$.

b. Materi sudah baik, khususnya untuk pembelajaran pemrograman CNC dasar tahap awal, yaitu mampu menampilkan simulasi gerakan pahat yang merupakan jalannya eksekusi program $\mathrm{CNC}$, pengguna dapat bebas membuat kombinasi kode-kode program $\mathrm{CNC}$ yang dimasukkan, melihat dan mengamati jalannya eksekusi program CNC yang dibuat pada layar komputer, dan mengetahui hasil eksekusi program CNCnya. 


\section{Daftar Pustaka}

Agung, Novian. (2004). Panduan microsoft visual basic. Yogyakarta: Penerbit Andi.

Emco Meier. (1992). Manual programing CNC TU-2A. Austria: Emco Meier.

Groover, Mikel P., \& Zimmers, Emory W. Jr. (1984). Computer design and manufacturing. New York: Prentice-Hall International, Inc.

Sidi, I. D. (2001). Menuju masyarakat belajar, menggagas paradigma baru pendidikan. Jakarta: Paramadina kerjasama Logos Wacana Ilmu.

Pannen, P., dkk.. (1999). Cakrawala pendidikan. Jakarta: Universitas Terbuka.

Soenarto. (2005). Metodologi Penelitian Pengembangan Untuk Peningkatan Kualitas Pembelajaran. Departemen Pendidikan Nasional: Direktorat Pembinaan Tenaga Kependidikan dan Ketenagaan Pendidikan Tinggi (PPTK dan KPT).

Sommerville, Ian. (2003). Software engineering, rekayasa perangkatl lunak. Jakarta: Penerbit Erlangga

Team. (2004). Software testing guide book part 1: Fundamentals of software testing. Software Testing Research Lab: http://www.SofTReL.org

Wen-Chai Song \& Shih-Ching Ou. (2003). Using virtual reality modelling to improve training techniques. Taiwan: National Central University

Williams, Laurie. (2004). Testing overview and black-box testing techniques. 